\title{
REKAYASA SISTEM INFORMASI MANAJEMEN PERAKITAN BERBASIS GROUP TECHNOLOGY UNTUK MENDUKUNG PROSES ASSEMBLY FRAME BODY BUS
}

\author{
Danang Murdiyanto ${ }^{1}$, Pratikto 2 , Purnomo Budi Santoso ${ }^{3}$ \\ 1 Universitas Katolik Widya Karya Malang \\ 2, 3Teknik Mesin Fakultas Teknik Universitas Brawijaya Malang \\ Jalan Mayjen Haryono 167 Malang 65145-Telp. (0341)567886 \\ Email: danang_dry@yahoo.com
}

\begin{abstract}
PT. APW is a manufacturing company of the bus body. One of the production process department in PT. APW is frame work department. It is in charge of making the bus body frame. The problem faced in this department is inadequationvof the current system. It is because the work is done manually and is not by using computer applications with database systems. The study used the assembly information management system based on Group Technology to help its assignment of bus body frame assembling process and the work report. Management Information System Design Assembly (SIMPER) were performed by using the Microsoft Access 2013 to produce a prototype application SIMPER consisting of phase identification, analyzing, planning, designing, implementating and testing. By designing this SIMPER prototype application, it is expected to meet the needs of users of information systems in Production Manager, SPV and Admin employees.
\end{abstract}

Keywords: Management Information Systems, Database, Assembly, Group Technology, Prototype

\section{PENDAHULUAN}

Perkembangan industri di Indonesia mengalami perkembangan yang semakin pesat, terutama industri yang bergerak di bidang karoseri. Dalam persaingan industri karoseri sekarang ini mendorong perlunya perencanaan yang baik dalam proses assembly atau perakitan dengan tanpa mengabaikan kualitas yang dihasilkan.

PT. APW merupakan salah satu industri karoseri yang bergerak dalam bidang pembentukan body kendaraan. Pembentukan body kendaraan yang dilakukan melibatkan proses assembly atau perakitan. Jenis kendaraan yang banyak di produksi PT. APW adalah jenis kendaraan besar yaitu bus. Dengan visi menjadi suatu perusahaan jasa yang menghasilkan produk yang berkualitas, maka PT. APW selalu melakukan secara terus menerus untuk memperbaiki proses produksinya. Pembuatan body kendaraan bus tidak dapat lepas dari proses assembly rangka atau frame. Adapun bagian-bagian dari frame body bus seperti pada Gambar 1.

Proses assembly terkadang merupakan sebuah pekerjaan yang rawan kesalahan [1], terlebih lagi bila terdapat banyak komponen yang harus dirakit. Begitu pula dalam proses perakitan frame body bus, banyak aktifitas yang terlibat di lantai kerja seperti komponen, mesin dan teknisi yang terintegrasi membentuk suatu alur produksi yang terdapat didalamnya maka perlu membutuhkan penanganan dan pengaturan yang baik.

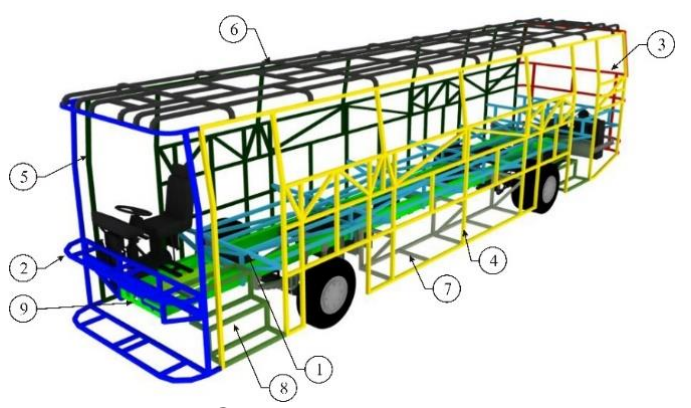

Gambar 1. Chassis dan Frame body bus
Keterangan:
1. Floor frame
6. Roof frame
2. Front frame
7. Baggage frame
3. Rear frame
8. Stair frame
4. Left side frame
5. Right side frame
9. Chassis bus 
Proses analisa dan identifikasi setiap tahap perakitan yang sedang berlangsung di lantai kerja departemen frame PT. APW pada penelitian ini sangatlah penting untuk mengetahui permasalahan-permasalahan yang ada untuk dilakukan perbaikan dalam membantu proses perakitan frame body bus.

Permasalahan yang mendasar pada departemen kerja frame body bus PT. APW adalah metode yang digunakan saat ini belum memadai karena masih dilakukan secara manual paper, pencil dan belum memanfaatkan aplikasi perangkat lunak atau software dengan sistem database. Permasalahan berikutnya adalah kompleksitas data informasi dari komponen, teknisi, jenis pekerjaan yang sangat bervariasi sehingga membutuhkan kejelian dan pengetahuan ketika melakukan proses perancangan dalam hal assembly frame body bus.

Berdasarkan kondisi yang terjadi pada departemen kerja frame PT. APW, kemudian mendasari perlunya dirancang Sistem Informasi Manajemen Perakitan (SIMPER) dengan didukung sistem database. Dalam memudahkan mengolah database digunakan proses pengelompokan dan pengkodean yang dapat dikembangkan dalam mendukung perancangan yaitu dengan menggunakan Group Technology (GT). Konsep GT merupakan suatu cara dalam manufaktur dimana komponen-komponen yang memiliki kesamaan akan dikelompokkan dengan tujuan untuk efisiensi dan menghasilkan produktifitas yang lebih baik. Dengan konsep GT, akan sangat membantu dalam mengklasifikasi setiap komponen menurut proses kerja dan parameternya sehingga dapat meningkatkan kinerja dan efisiensi dalam perancangan proses produksi pada perakitan frame body bus.

\section{METODOLOGI PENELITIAN}

Fame Body bus yang digunakan dalam simulasi berasal dari perusahaan PT. APW Malang. Solusi dari pemecahan masalah yang bermanfaat bagi industri yang melibatkan proses assembly didapatkan dari hasil penelitian melalui simulasi yang berupa sistem pendukung keputusan dan pengontrolan akan proses assembly pada pembuatan frame body bus.

Proses dari analisa dan perancangan dari sistem ini dilakukan sebagai tahap awal pembuatan suatu program. Analisa digunakan untuk mengetahui apa saja yang dibutuhkan oleh sistem. Perancangan sistem dilakukan dengan cara membuat konsep terlebih dahulu, kemudian dibuat sesuai degan keinginan yang mengacu pada konsep dasar. Tahap selanjutnya setelah pembuatan sistem selesai akan dilakukan pengujian dengan uji verifikasi, uji validasi dan uji prototype.

\section{Proses Assembly}

Proses diartikan sebagai suatu cara, metode, dan teknik bagaimana sesungguhnya sumber-sumber seperti tenaga kerja, mesin dan bahan yang ada diubah untuk memperoleh suatu hasil. Sedangkan assembly atau perakitan merupakan suatu pekerjaan yang diawali dari objek atau komponen-komponen yang sudah siap untuk dipasang hingga proses tersebut terpasang secara sempurna. Suatu proses assembly atau perakitan dapat dilakukan secara manual maupun otomatis. Contoh proses assembly antara lain proses pengikatan, pengelingan, pengelasan, penyekrupan dan sebagainya dalam urutan perakitannya. Hal ini dilakukan untuk mendapatkan bentuk yang standar pada setiap hasil produknya.

\section{Shop Floor}

Shop floor dalam industri manufaktur dapat diartikan merupakan suatu bagian dalam fasilitas manufaktur dimana di dalamnya melibatkan aktivitas suatu proses perakitan atau produksi yang dilakukan baik dengan menggunakan sistem otomatis, pekerja atau dapat dilakukan dengan menggunakan kombinasi keduanya. Shop floor dalam industri manufaktur juga termasuk melibatkan antara lain unsur peralatan, persediaan dan area penyimpanan.

\section{Sistem Database}

Database (basis data) merupakan suatu susunan atau kumpulan data operasional lengkap dari suatu organisasi atau perusahaan atau departemen kerja yang diorganisir atau dikelola dan disimpan secara terintegrasi dengan menggunakan metode tertentu dan dengan menggunakan komputer sehingga mampu menyediakan informasi optimal yang diperlukan pemakainya serta data disimpan sedemikian sehingga penambahan, 
pengambilan dan modifikasi data dapat dilakukan dengan mudah dan terkontrol.

Database secara umum mempunyai tujuan [2], yaitu:

1. Isolasi data, bahwa database dapat menempatkan tiap data pada masingmasing tempat.

2. Multi user, yaitu saat perusahaan mengambil pendekatan berorientasi masalah, pertama didefinisikan kemudian pengambilan keputusan diperlukan informasi.

\section{Software Prototype}

Terdapat empat tahapan dalam pengembangan software menggunakan aplikasi prototype. Langkah pertama adalah menetapkan tujuan prototype dengan mengidentifikasi masalah pada sistem yang akan dibuat. Langkah kedua yaitu mendefinisikan fungsi prototype sehingga sesuai dengan kebutuhan user. Langkah ketiga yaitu mengembangkan prototype dengan merancang desain logis hingga implementasi dari konsep yang telah dibuat. Langkah terakhir adalah pengujian prototype yang dilakukan dengan uji validasi, uji verifikasi dan uji prototype [3].

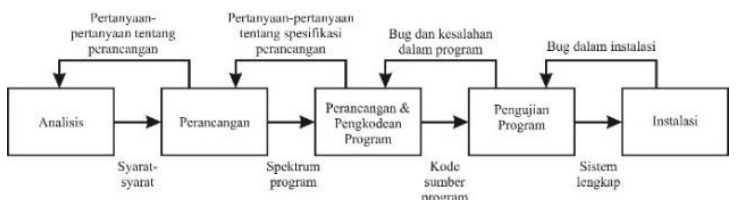

Gambar 2. Model Proses Pengembangan Prototype

\section{System Requirement Checklist (SRC)}

SRC merupakan barometer dari ukuran kesuksesan suatu prototype sekaligus merupakan kumpulan karakteristik yang harus disertakan ke dalam sistem informasi guna memenuhi kebutuhan, sehingga dapat diterima oleh pengguna. Kebutuhan dari sistem dapat digambarkan ke dalam lima kategori umum, seperti Tabel 1.

Tabel 1. System Requirement Checklist (SRC)

\begin{tabular}{cl}
\hline Komponen & \multicolumn{1}{c}{ Keterangan } \\
\hline \multirow{3}{*}{ Input } & $\begin{array}{l}\text { Data komponen frame body } \\
\text { bus pada departemen frame } \\
\end{array}$ \\
& PT. APW
\end{tabular}

Output

Process

Performance

Control
Report jumlah perencanaan proses assembly setiap hari Pengolahan dari proses assembly

Sistem terintegrasi dalam proses assembly sehingga data selalu ter-update dengan cepat.

Hak untuk melakukan akses dari tiap proses kerja assembly sesuai dengan kapasitas.

\section{Group Technology}

Group Technology (GT) merupakan suatu filosofi dalam manufaktur yang mengidentifikasi keserupaan komponen-komponen kemudian mengelompokkannya bersama dengan mengambil keuntungan dari keserupaan dalam desain dan manufaktur. Konsep dasar dari GT adalah menyederhanakan dan standardisasi proses [4].

Sistem pengkodean terbagi menjadi tiga macam [5], yaitu:

1. Monocode (Struktur Hirarki)

Tipe pengkodean monocode (struktur hirarki) ini masing-masing digit akan memperkuat informasi dari digit sebelumnya. Hal ini mengindikasikan suatu deretan atau urutan kode pada setiap digit yang ada bergantung pada karakter digit sebelumnya. Digit pertama adalah mewakili seluruh group dan digit selanjutnya mewakili kelompok subsection dan seterusnya, seperti Tabel 3 .

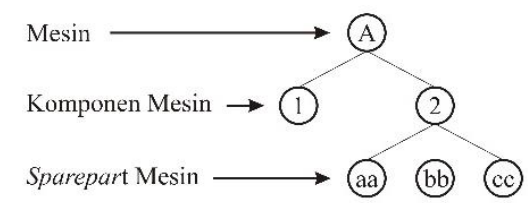

Gambar 3. Hierakis Klasifikasi Sparepart

\section{Polycode (Kode Atribut)}

Konsep dari pengkodean tipe polycode atau chain-structure memiliki arti bahwa masingmasing digit kode yang digunakan tidak tergantung pada deretan kode sebelum digit kode inisehingga dapat mengakomodasi setiap perubahan. Pada konsep kode ini, masingmasing bagian dalam kode mempunyai posisi yang spesifik. Struktur dari pengkodean sangat mudah diterapkan, tetapi jumlah digit yang 
besar memerlukan perwakilan karakteristik dari suatu section.

Tabel 2. Tipe pengkodean monocode (struktur hirarki)

\begin{tabular}{cccc}
\hline Digit & Lokasi & $\mathbf{1}$ & $\mathbf{2}$ \\
\hline 1 & Area & Lemari A & Lemari B \\
2 & Rak & Rak 2 & Rak 2 \\
$\ldots$ & $\ldots$ & $\ldots$ & $\ldots$ \\
\hline
\end{tabular}

\section{Hybrid}

Pengkodean tipe ini digunakan dengan sistem penggabungan dari tipe pengkodean monocode dan polycode, dalam hal ini dengan memanfaatkan keuntungan dari setiap karakteristik sistem kodefikasi monocode dan polycode yang seperti di tunjukkan contoh Gambar 4.

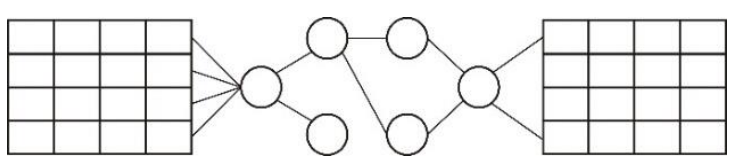

Gambar 4. Kode Atribut Inventory

\section{HASIL DAN PEMBAHASAN}

Model kebutuhan sistem dimasukkan ke dalam lima kategori umum System requirement 7. Checklist (SRC), yaitu output, input, process, performance dan control. Berikut adalah spesifikasi kebutuhan kebutuhan sistem informasi manajemen perakitan yang diperoleh oleh SRC:
1. Sistem dapat diakses oleh Manager Produksi, Supervisor (SPV) dan admin karyawan dengan hak akses dan fungsi yang berbeda untuk proses login, yaitu username dan password.

2. Sistem dapat memberikan informasi penugasan kerja untuk SPV dan karyawan.

3. Sistem dapat memberikan laporan kerja yang dibutuhkan oleh SPV, dan laporan kerja SPV yang dibutuhkan oleh Manager Produksi.

Sistem yang dirancang disesuaikan model kebutuhan (requirement modelling) pada departemen kerja frame body bus PT. APW seperti Gambar 5 dibawah. Untuk menggambarkan logika dari kebutuhan sistem informasi manajemen perakitan tentang aliran dari informasi dalam sistem digunakan Data Flow Diagram (DFD) seperti pada Gambar 6.

\section{Desain Kodefikasi dengan GT}

Klasifikasi dan kodefikasi GT yang digunakan dalam merancang database yaitu dengan sistem hybrid, dimana pada sistem pengkodean ini menggabungkan pengkodean sistem monocode dengan pengkodean polycode. Sistem kode yang dirancang ini bersifat universal, sehingga dapat diterapkan pada departemen kerja frame body bus di PT. APW yang diadaptasi dari Opitz seperti Gambar 7. 


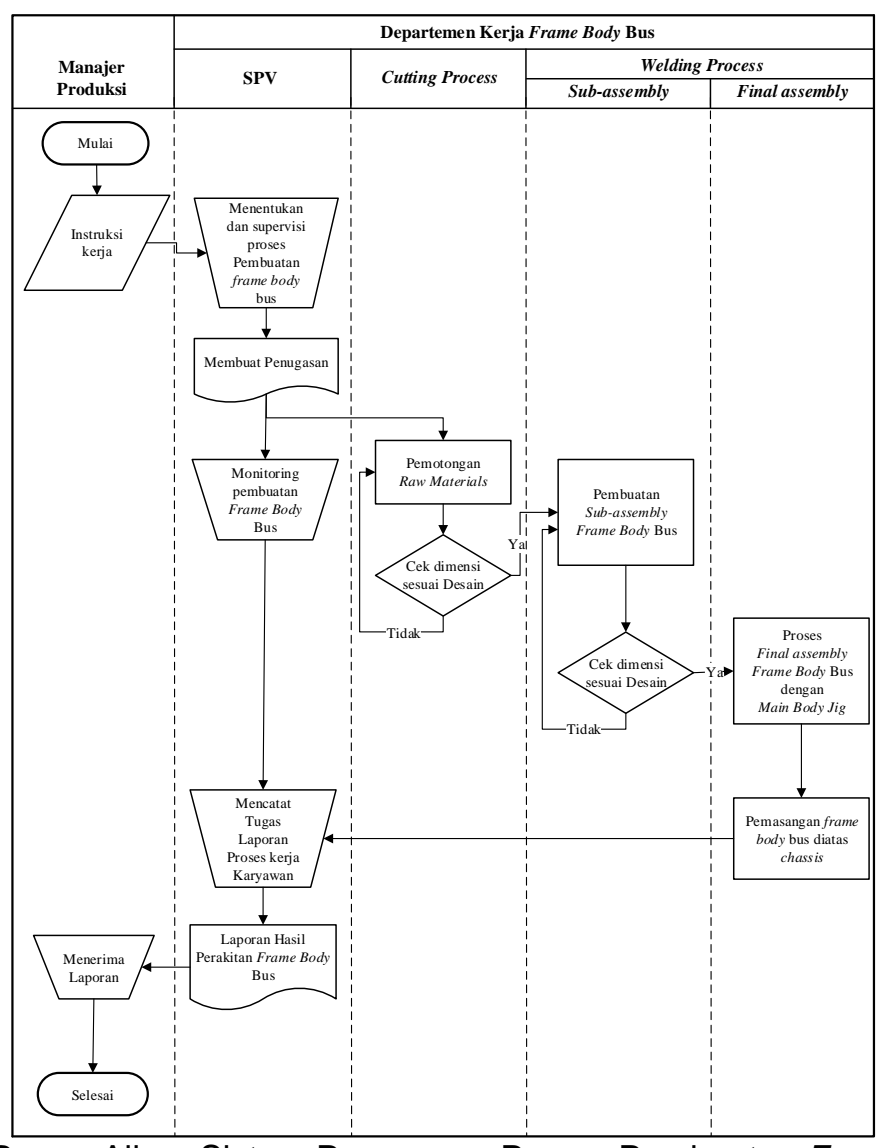

Gambar 5. Bagan Aliran Sistem Penugasan Proses Pembuatan Frame Body Bus.

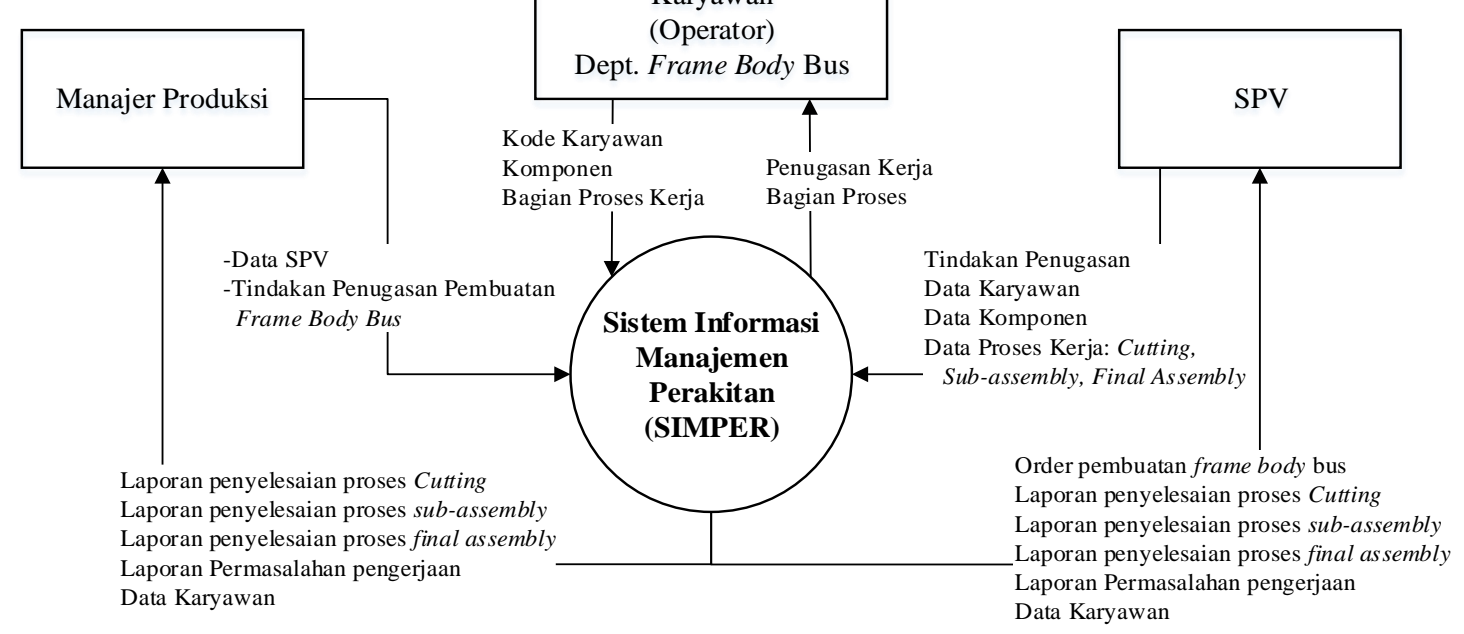

Gambar 6. Context Diagram 


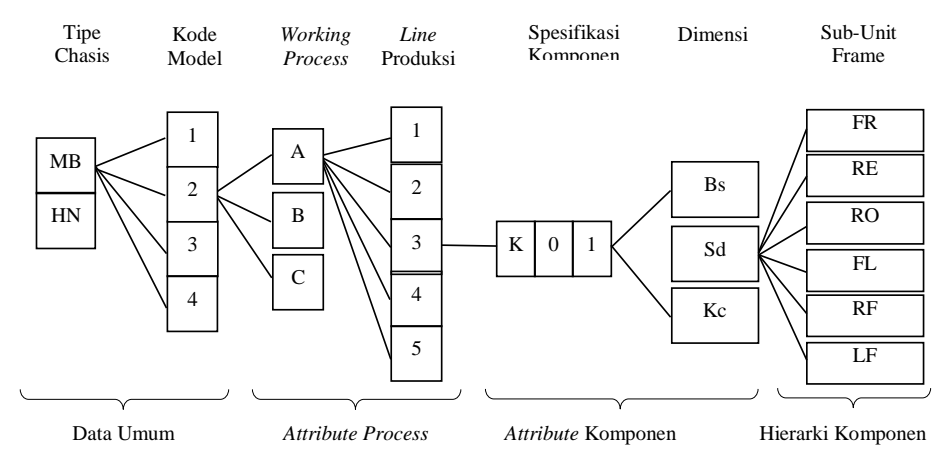

Gambar 7. Konsep Group Technology dengan Sistem Kodefikasi Hybrid

Sebelum dibuat tabel data maka dibutuhkan parameter yang digunakan konsep pengkodean hybrid berdasarkan parameter kodefikasi.

Tabel 3. Parameter Kodefikasi

\begin{tabular}{|c|c|c|c|c|}
\hline Parameter & Entity & Atribut & Kode & Ket. \\
\hline \multirow{6}{*}{ Data Umum } & & Mercedes Benz & $\mathrm{MB}$ & \\
\hline & I Ipe Chasıs & Hino & $\mathrm{HN}$ & digit $1-2$ \\
\hline & \multirow{4}{*}{ Kode Model } & $\mathrm{MB} \mathrm{OH} 1836$ & 1 & \multirow{4}{*}{ digit 3} \\
\hline & & $\mathrm{MB} \mathrm{OH} 475$ & 2 & \\
\hline & & J08E-UH & 3 & \\
\hline & & J08E-UG & 4 & \\
\hline \multirow{8}{*}{$\begin{array}{l}\text { Attribute } \\
\text { Process }\end{array}$} & \multirow{3}{*}{ Working process } & Cutting & $A$ & \multirow{3}{*}{ digit 4} \\
\hline & & Sub-assembly & $\mathrm{B}$ & \\
\hline & & Final Assembly & C & \\
\hline & \multirow{5}{*}{ Line Produksi } & Line 1 & 1 & \multirow{2}{*}{ digit 5} \\
\hline & & Line 2 & 2 & \\
\hline & & Line 3 & 3 & \multirow{11}{*}{ digit 6-7-8 } \\
\hline & & Line 4 & 4 & \\
\hline & & Line 5 & 5 & \\
\hline \multirow{17}{*}{$\begin{array}{c}\text { Attribute } \\
\text { Komponen }\end{array}$} & \multirow{8}{*}{$\begin{array}{l}\text { Spesifikasi } \\
\text { komponen }\end{array}$} & Cross Member & K01 & \\
\hline & & Support Cross Member & K02 & \\
\hline & & Middle Support & K03 & \\
\hline & & Pilar Frame & K04 & \\
\hline & & Top Support Frame & K05 & \\
\hline & & Bottom Support Frame & K06 & \\
\hline & & Longitudional Frame & K07 & \\
\hline & & Varian nama & & \\
\hline & \multirow{3}{*}{ Dimensi } & Besar $(>3 m)$ & Bs & \multirow{3}{*}{ digit 9-10 } \\
\hline & & Sedang $(1-3 m)$ & $\mathrm{Sd}$ & \\
\hline & & Kecil $(<1 \mathrm{~m})$ & Kc & \\
\hline & \multirow{6}{*}{$\begin{array}{c}\text { Hierarki } \\
\text { Komponen }\end{array}$} & Front Frame & FR & \multirow{6}{*}{ digit $11-12$} \\
\hline & & Rear Frame & $\mathrm{RE}$ & \\
\hline & & Roof Frame & RO & \\
\hline & & Floor Frame & $\mathrm{FL}$ & \\
\hline & & Right-side Frame & $\mathrm{RF}$ & \\
\hline & & Left-side Frame & LF & \\
\hline
\end{tabular}


Sebagai ilustrasinya dapat digambarkan seperti contoh pengkodean komponen pada Gambar 8.

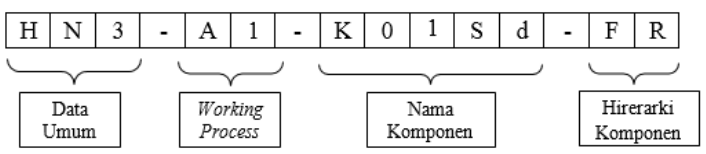

Gambar 8. Contoh Kodefikasi Komponen

Dari contoh pengkodean 12 digit diatas dengan berdasarkan tabel parameter kodefikasi dapat didefinisikan sebagai berikut:

A. Data umum: HN3, mengartikan tipe chassis Hino dengan tipe kode chasis J08E-UH

B. Working process: A1, mengartikan komponen tersebut dikerjakan pada proses cutting dibuat pada line produksi 1

C. Nama Komponen: K01Sd, mengartikan nama komonennya yaitu Cross Member dengan dimensi komponen adalah berukuran sedang $1-3 m$

D. Hierarki Komponen: FR, mengartikan komponen nama bagian sub-assembly frame body bus dengan nama Front Frame

\section{Desain Database}

Pada tahap membuat desain database dilakukan dengan tujuan mengubah model informasi dari tahap analisis sistem menjadi model yang sesuai dengan implementasi sistem. Adapun langkah-langkah untuk membuat desain database antara lain yaitu desain database logis, normalisasi dan desain database fisik.

\section{Desain Database Logis}

Dalam dessain database logis ini menjelaskan fungsi-fungsi pada SIMPER kepada pengguna atau user akan berkerja secara logika. Desain database logis disini menggambarkan entitas dan atribut yang terlibat dalam SIMPER. Entitas dan atribut akan digambarkan dengan entity relationship diagram (ERD).

\section{Desain Database Fisik}

Desain database fisik dalam penelitian ini adalah merupakan aktualisasi dari desain database logis yang digunakan dalam mendukung pembuatan sistem informasi dengan menggunakan software. Software yang dakam perencanaan sistem informasi ini adalah Microsoft Access 2013.

Tabel 4. Desain Fisik Entitas BOM

\begin{tabular}{|c|c|c|c|c|}
\hline Field & $\begin{array}{l}\text { Data } \\
\text { Type }\end{array}$ & $\begin{array}{c}\text { Field } \\
\text { Size }\end{array}$ & Desc. & PK \\
\hline $\begin{array}{l}\text { Kode_B } \\
\text { OM }\end{array}$ & $\begin{array}{l}\text { Short } \\
\text { Text }\end{array}$ & 15 & Kode BOM & $P K$ \\
\hline $\begin{array}{l}\text { Kode } \\
\text { Data } \\
\text { Umum }\end{array}$ & $\begin{array}{l}\text { Short } \\
\text { Text }\end{array}$ & 50 & $\begin{array}{l}\text { Data umum: } \\
\text { chassis }\end{array}$ & \\
\hline $\begin{array}{l}\text { Kode } \\
\text { Proses }\end{array}$ & $\begin{array}{l}\text { Short } \\
\text { Text }\end{array}$ & 2 & $\begin{array}{l}\text { Proses dan } \\
\text { Line } \\
\text { produksi }\end{array}$ & \\
\hline $\begin{array}{l}\text { Kode } \\
\text { Kompone } \\
\text { n }\end{array}$ & $\begin{array}{l}\text { Short } \\
\text { Text }\end{array}$ & 5 & $\begin{array}{l}\text { Kode } \\
\text { komponen } \\
\text { dan dimensi }\end{array}$ & \\
\hline $\begin{array}{l}\text { Kode } \\
\text { Sub- } \\
\text { assembly }\end{array}$ & $\begin{array}{l}\text { Short } \\
\text { Text }\end{array}$ & 2 & $\begin{array}{l}\text { Kode bagian } \\
\text { sub- } \\
\text { assembly }\end{array}$ & \\
\hline $\begin{array}{l}\text { Definisi } \\
\text { BOM }\end{array}$ & $\begin{array}{l}\text { Short } \\
\text { Text }\end{array}$ & 250 & $\begin{array}{l}\text { Definisi dari } \\
\text { BOM }\end{array}$ & \\
\hline
\end{tabular}

3. Desain User Interface

Perancangan user interface pada SIMPER dengan tujuan supaya memudahkan user dalam menggunakan aplikasi. Tahap desain user interface sendiri terbagi menjadi beberapa tahap yaitu desain hierarki, desain model user interface form, dan desain report.

A. Desain hierarki

Dalam rancangan user interface di desain dengan tampilan menu awal yang menampilkan form login, fungsinya adalah untuk memasukkan nama user dan password untuk masuk ke menu utama.

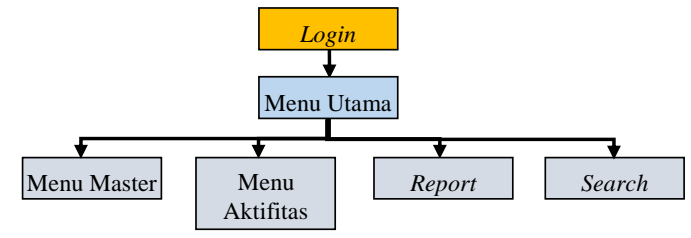

\section{Gambar 9. Desain Menu SIMPER}

Desain menu SIMPER menunjukkan bahwa untuk masuk ke dalam menu utama, user harus melakukan login dengan 
memasukkan sesuai user name dan password masing-masing.

B. Desain model user interface form

Dalam desain model user interface form disini merupakan tahap merancang tampilan dari prototype yang dibuat, sehingga pengguna atau user dapat menggunakan lebih mudah dan agar lebih komunikatif. Desain model user interface seperti pada Gambar 10.

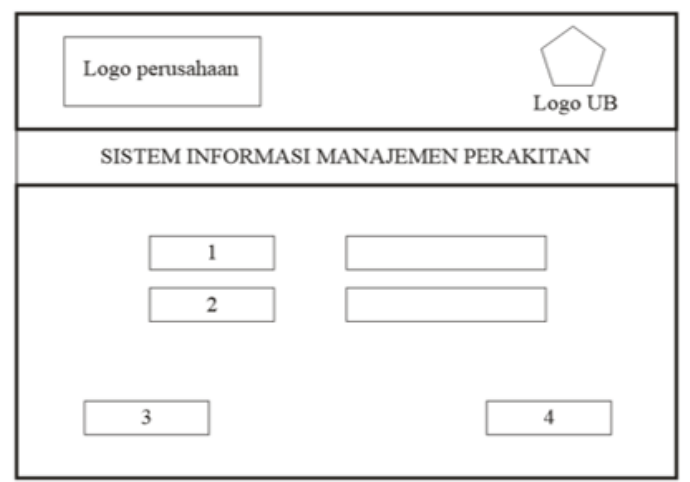

Keterangan:
1. User Name
3. Login
2. Password
4. Exit

Gambar 10. Desain Model User Interface

C. Desain report

Sistem informasi manajemen perakitan menghasilkan report yang digunakan oleh Manager Produksi dan SPV dalam mengambil kebijakan untuk penugasan kerja, monitoring dan evaluasi kerja di departemen kerja frame body bus PT. APW. Desain report dalam sistem informasi manajemen perakitan ini adalah:

1) Report Hasil Kerja Karyawan

Dalam Report hasil kerja karyawan berisi data yang berhubungan dengan hasil penugasan karyawan setelah dijalankan. Report ini memberikan informasi sebagai penilaian dan evaluasi proses kerja antara lain informasi hasil kerja karyawan tentang tanggal dan hari dimulainya pekerjaan, tanggal dan hari tugas kerja selesai dikerjakan, nama komponen, jumlah komponen yang dikerjakan dan status pekerjaan yang menginformasikan suatu pekerjaan selesai tepat waktu atau melewati dari batas waktu yang ditentukan serta keterangan jika terjadi kendala pada proses pengerjaan.

\section{2) Report Laporan SPV}

Report laporan SPV merupakan laporan hasil proses kerja yang berlangsung di departemen kerja frame body bus dari proses penugasan, jalannya pekerjaan pembuatan frame hingga final assembly. Report ini ditujukan untuk manager produksi sebagai evaluasi kerja SPV.

\section{Implementasi}

Langkah implementasi pada penelitian ini merupakan tahap membuat aplikasi ke dalam prototype dari spesifikasi dan konsep yang dirancang dengan database, module dan interface menggunakan Microsoft Access 2013. Tahap implementasi selain memasukkan komponen-komponen yang terlibat dalam perencanaan tetapi juga mengatur hubungan serta kesesuaian antara data yang dibuat.

1. Implementasi database, tahap ini dimulai dari pembuatan tabel-tabel kebutuhan dari sistem.

2. Relasi antar tabel, pada SIMPER terdapat 12 entitas dengan relasi berdasarkan ERDseperti pada Gambar 11.

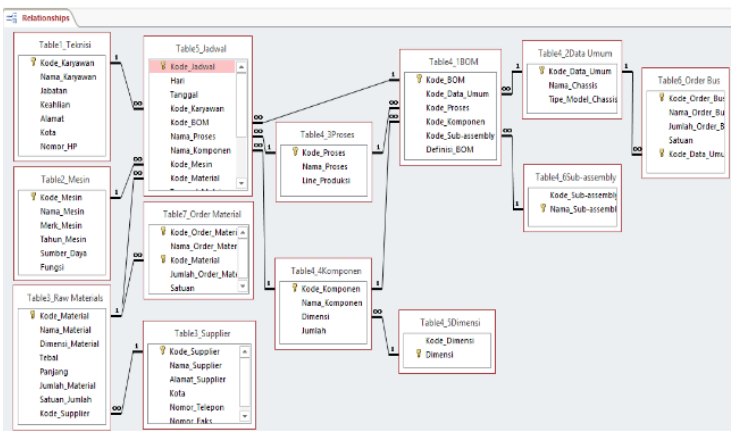

\footnotetext{
Gambar 11. Printscreen Desain Relasi antar Tabel
}

3. Implementasi user interface

Tahap implementasi user interface bertujuan supaya pengguna atau user lebih mudah dalam mengakses dan menggunakan aplikasi SIMPER. Sebagai contoh implementasi login seperti pada Gambar 12. 


\section{adiputro}

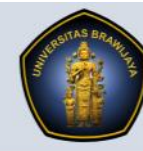

SISTEM INFORMASI MANAJEMEN PERAKITAN

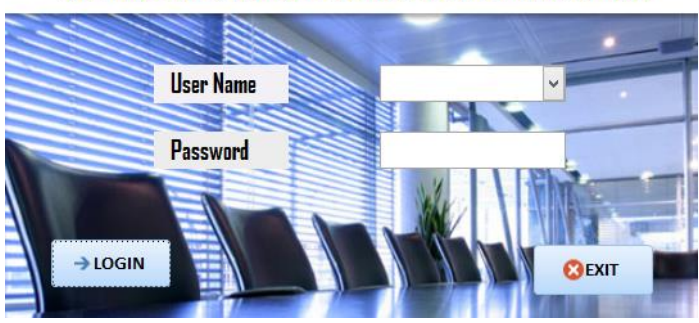

Gambar 12. Printscreen Menu Login

4. Implementasi menu report

Sedangkan implementasi user interface dari menu report dengan berdasarkan konsep desain yang telah direncanakan untuk mempermudah user dalam mengetahui laporan kerja.

5. Implementasi form penugasan

Implementasi form penugasan kerja dibuat berdasarkan informasi yang dibutuhkan karyawan untuk menjalankan tugasnya.

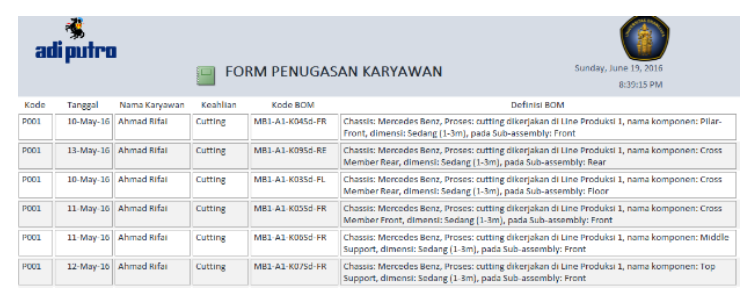

Gambar 14. Printscreen Form

Penugasan untuk Karyawan

6. Implementasi form report Implementasi dari desain form sebagai laporan hasil kerja karyawan seperti pada Gambar 15.

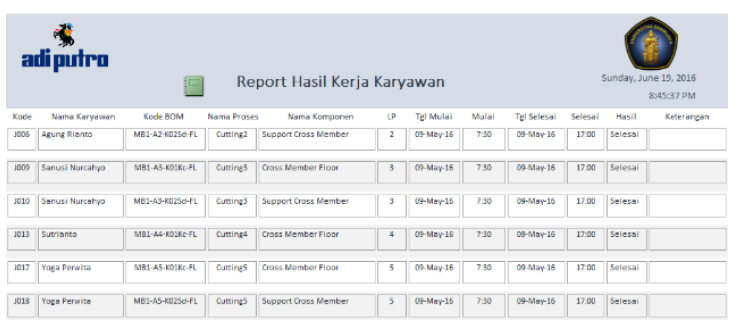

Gambar 15. Printscreen Form Report Karyawan

\section{Pengujian Sistem}

Pada tahap akhir setelah rancangan sistem sudah menjadi prototype yaitu tahapan pengujian. Tahapan pengujian prototype ini dilakukan dengan tujuan untuk membuktikan keunggulan penggunaan dari metode aplikasi prototype SIMPER dibandingkan dengan metode yang digunakan sementara ini di perusahaan PT. APW pada departemen kerja pembuatan frame body bus.

Adapun dalam tahan pengujian prototype ini meliputi uji verifikasi, uji validasi dan uji prototype.

1. Uji Verifikasi

Tahap pengujian verivikasi secara umum adalah untuk menguji apakah prototype SIMPER sudah sesuai dengan desain sistem yang dibuat, dalam hal ini tahap ini juga berguna untuk menyingkronisasi agar implementasi prototype berfungsi dalam mendukung data proses perakitan frame seperti yang diharapkan.

2. Uji Validasi

Pada tahap validasi ini adalah untuk mengetahui apakah fungsi prototype sudah sesuai dengan yang diharapkan dan mempresentasikan tujuan awal dengan berdasarkan user requirement yang dijabarkan dalam System Requirement Checklist (SRC).

Tabel 5. Uji Validasi SIMPER

\section{Pengguna Kebutuhan Pengguna yang} Dipenuhi

Manager Dari aplikasi SIMPER, Manager

Produksi Produksi dapat memasukkan data sebagai penugasan kepada penanggung jawab departemen kerja pembuatan frame body bus yaitu SPV.

Selain melakukan pengawasan kerja secara langsung, Manager Produksi dapat memonitoring kerja SPV dan seluruh karyawan pada departemen kerja frame body bus dengan menggunakan aplikasi SIMPER Manager Produksi mendapatkan report hasil kerja pembuatan frame body bus melalui form laporan SPV yang 


\begin{tabular}{|c|c|}
\hline & $\begin{array}{l}\text { digunakan sebagai bahan } \\
\text { evaluasi kerja. }\end{array}$ \\
\hline \multirow[t]{4}{*}{ SPV } & $\begin{array}{l}\text { Dari aplikasi SIMPER, SPV } \\
\text { dapat melakukan penugasan } \\
\text { kerja kepada karyawan pada } \\
\text { departemen kerja pembuatan } \\
\text { frame body bus. }\end{array}$ \\
\hline & $\begin{array}{l}\text { SIMPER dapat memberikan } \\
\text { informasi akan komponen, sub- } \\
\text { assembly hingga proses final } \\
\text { assembly, jadwal kerja dan } \\
\text { mesin. }\end{array}$ \\
\hline & $\begin{array}{l}\text { Selain melakukan pengawasan } \\
\text { kerja secara langsung di lantai } \\
\text { kerja pembuatan frame, SPV } \\
\text { dapat memonitor seluruh } \\
\text { pekerjaan pembuatan frame } \\
\text { dengan menggunakan aplikasi } \\
\text { SIMPER. }\end{array}$ \\
\hline & $\begin{array}{l}\text { SPV mendapatkan report hasil } \\
\text { kerja karyawan }\end{array}$ \\
\hline \multirow[t]{2}{*}{ Karyawan } & 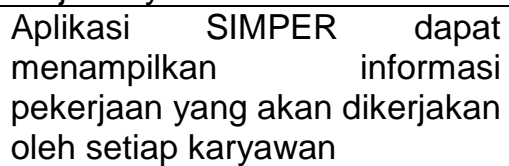 \\
\hline & $\begin{array}{lll}\text { Aplkasi } & \text { SIMPER } & \text { dapat } \\
\text { menyajikan informasi } & \text { target } \\
\text { penyelesaian pekerjaan } & \end{array}$ \\
\hline
\end{tabular}

\section{Uji Prototype}

Tahapan terakhir dalam pengujian prototype ini adalah uji prototype sendiri, tahap uji prototype bertujuan untuk mengetahui bahwwa aplikasi prototype yang telah dirancang dan dibuat apakah sudah mengatasi kelemahan dan masalah dengan cara lama.

Tabel 6. Perbandingan performa Antara Sistem

\begin{tabular}{|c|c|}
\hline \multicolumn{2}{|c|}{ Lama dan Sistem Baru } \\
\hline Sistem Lama & Sistem Baru \\
\hline $\begin{array}{l}\text { - Keamanan } \\
\text { tidak baik karena } \\
\text { data } \\
\text { disimpan secara } \\
\text { manual, sehingga } \\
\text { data rawan rusak } \\
\text { dan hilang. }\end{array}$ & $\begin{array}{l}\text { - Keamanan data } \\
\text { lebih baik karena } \\
\text { data sudah } \\
\text { tersimpan secara } \\
\text { komputerisasi, } \\
\text { sehingga dalam } \\
\text { permasalahan } \\
\text { hilangnya data } \\
\text { dapat berkurang. }\end{array}$ \\
\hline $\begin{array}{l}\text { - Masih } \\
\text { kendala }\end{array}$ & $\begin{array}{l}\text { - Penelusuran data } \\
\text { sudah mudah }\end{array}$ \\
\hline
\end{tabular}

\begin{tabular}{|c|c|}
\hline Sistem Lama & Sistem Baru \\
\hline $\begin{array}{l}\text { menelusuri } \\
\text { informasi data atau } \\
\text { arsif data karena } \\
\text { penyimpanan masih } \\
\text { secara manual. }\end{array}$ & $\begin{array}{l}\text { karena semua data } \\
\text { masuk dalam } \\
\text { database SIMPER. }\end{array}$ \\
\hline $\begin{array}{l}\text { - Proses } \\
\text { penyimpanan masih } \\
\text { dilakukan secara } \\
\text { manual, sehingga } \\
\text { akan rentan } \\
\text { terhadap terjadinya } \\
\text { kesalahan pada } \\
\text { saat proses input } \\
\text { data. }\end{array}$ & $\begin{array}{l}\text { - Proses } \\
\text { penyimpanan } \\
\text { sudah } \\
\text { menggunakan } \\
\text { sistem database, } \\
\text { sehingga proses } \\
\text { input data akan } \\
\text { lebih mudah baik } \\
\text { dalam } \\
\text { penyimpanan } \\
\text { maupun edit data }\end{array}$ \\
\hline $\begin{array}{l}\text { - Proses } \\
\text { pengontrolan belum } \\
\text { optimal terhadap } \\
\text { proses penugasan } \\
\text { karena masih } \\
\text { dilakukan dengan } \\
\text { cara manual }\end{array}$ & $\begin{array}{l}\text { - Sistem baru } \\
\text { menyediakan } \\
\text { fasilitas tindakan } \\
\text { yang harus } \\
\text { dilakukan sesuai } \\
\text { keahlian sehingga } \\
\text { membantu } \\
\text { manager produksi } \\
\text { maupun SPV } \\
\text { untuk memberikan } \\
\text { kebijakan dalam } \\
\text { penugasan. }\end{array}$ \\
\hline $\begin{array}{l}\text { - Karyawan } \\
\text { mendapatkan } \\
\text { informasi } \\
\text { penugasan masih } \\
\text { secara lisan, } \\
\text { sehingga rentan } \\
\text { akan kesalahan } \\
\text { proses pengejaan }\end{array}$ & $\begin{array}{l}\text { - Sistem } \\
\text { menyediakan } \\
\text { form-form } \\
\text { penugasan kerja, } \\
\text { sehingga melalui } \\
\text { admin karyawan } \\
\text { mudah untuk } \\
\text { melihat tugas kerja } \\
\text { masing-masing. }\end{array}$ \\
\hline $\begin{array}{l}\text { - Pada sistem lama } \\
\text { belum } \\
\text { menggunakan } \\
\text { teknologi, sistem } \\
\text { masih } \\
\text { menggunakan } \\
\text { pencatatan data } \\
\text { dengan ditulis } \\
\text { manual, sehingga } \\
\text { memerlukan waktu } \\
\text { lama, rentan } \\
\text { kesalahan dan pada } \\
\text { proses } \\
\text { penyimpanan }\end{array}$ & $\begin{array}{l}\text { - } \text { Sistem sudah } \\
\text { menggunakan } \\
\text { perangkat lunak } \\
\text { atau software yang } \\
\text { mudah untuk } \\
\text { dijalankan dalam } \\
\text { mencatat, } \\
\text { melakukan edit } \\
\text { data dan } \\
\text { penyimpanan data. }\end{array}$ \\
\hline
\end{tabular}




\begin{tabular}{|c|c|}
\hline Sistem Lama & Sistem Baru \\
\hline $\begin{array}{l}\text { memerlukan ruang } \\
\text { atau tempat. }\end{array}$ & \\
\hline $\begin{array}{l}\text { - Dalam pencarian } \\
\text { data karyawan, } \\
\text { mesin, komponen } \\
\text { dan waktu proses } \\
\text { pengerjaan masih } \\
\text { manual dengan } \\
\text { cara melihat lagi } \\
\text { arsip-arsip } \\
\text { dokumen surat }\end{array}$ & $\begin{array}{l}\text { - Sistem } \\
\text { menyediakan } \\
\text { menu pencarian } \\
\text { atau search, } \\
\text { sehingga manager } \\
\text { produksi dan SPV } \\
\text { sangat mudah } \\
\text { untuk mencari data } \\
\text { karyawan, } \\
\text { komponen, mesin } \\
\text { atau proses kerja. }\end{array}$ \\
\hline 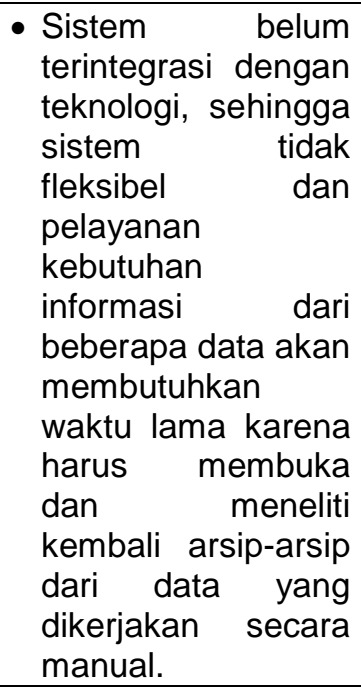 & $\begin{array}{lr}\text { - Sistem sudah } & \text { sulam } \\
\text { terintegrasi dalam } \\
\text { teknologi komputer } \\
\text { dan fleksibel jika } \\
\text { terdapat } \\
\text { perubahan data, } \\
\text { sehngga } \\
\text { pelayanan } \\
\text { kebutuhan } \\
\text { informasi semua } \\
\text { data mengenai } \\
\text { proses perakitan } \\
\text { frame body } \\
\text { busakan lebih } \\
\text { mudah. }\end{array}$ \\
\hline
\end{tabular}

\section{KESIMPULAN}

Hasil dari penelitian ini adalah aplikasi prototype sistem informasi manajemen perakitan yang berbasis Group Technology untuk mendukung proses assembly frame body bus di PT. APW. Dalam pembahasan menunjukkan bahwa rancangan database dengan menggunakan Group Technology dengan sistem hybrid sangat membantu dalam pembuatan aplikasi prototype SIMPER. Hasil rancangan SIMPER dalam pengoperasiannya sudah dapat memenuhi kebutuhan dilakukan oleh tiga pengguna atau user yang diberikan hak dalam mengakses sistem yaitu Manager Produksi, SPV dan Admin karyawan. Sistem informasi ini mampu untuk mengelola data proses kerja assembly frame body bus dari sistem penugasan hingga laporan kerja dalam informasi form yang dapat dicetak. Dari hasil analisis sistem informasi dalam penelitian ini yaitu, mampu mengatasi permasalahan pengelolaan sistem yang selama ini masih dijalankan secara manual.

\section{DAFTAR PUSTAKA}

[1]Choi. 1998. Panax ginseng C.A. Meyer: micro-propagation and the in vitro production of saponins. In: Bajai YPS (ed) Medicinal and aromatic plants (biotechnology in agriculture and forestry 4). Berlin: Springer.

[2]Raena M. \& Budi S. 2012. Design of Maintenance Management Information System Based on Group Technology, Teknik Industri Universitas Brawijaya.

[3]Sommerville, Ian. 2011. Software Engineering: Ninth Edition, AddisonWesley, United States of Amerika.

[4]Burbidge, J.L. 1975, The Introduction of Group Technology, Heinemann, London.

[5]Chang, T., Wysk, R.A. \& Wang, H. 2005. Computer Aided Manufacturing International series in Industrial and System Engineering. Prentice Hall. New Jersey. 
